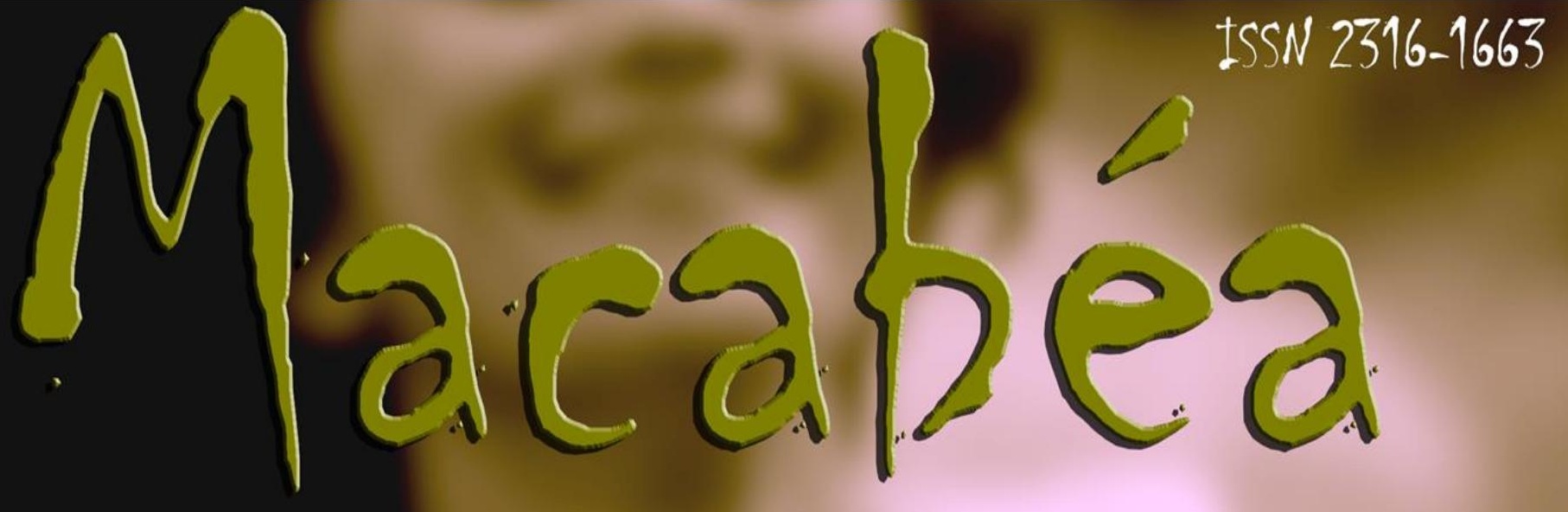

Revista Eletrônica do Netlli, Volume Q3, Nümero 2. Jul.-Dez, 2019

\title{
DESMISTIFICANDO A GRAMÁTICA GERATIVA COMO UMA TEORIA ASSOCIAL E A-HISTÓRICA DA MUDANÇA LINGUÍSTICA
}

\begin{abstract}
DEMISTIFYING GENERATIVE GRAMMAR AS AN ASOCIAL AND A-HISTORICAL THEORY OF LINGUISTIC CHANGE
\end{abstract}

Carlos Felipe da Conceição Pinto* UNIVERSIDADE FEDERAL DA BAHIA; UNIVERSIDADE ESTADUAL DE CAMPINAS; CAPES, Brasil

Aroldo Leal de Andrade UNIVERSIDADE FEDERAL DE MINAS GERAIS, Brasil

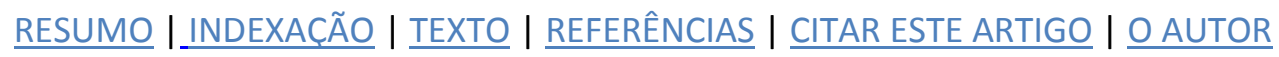
RECEBIDO EM 29/04/2019• APROVADO EM 05/05/2019 
Commonly a distinction is made between "diachronic linguistics" and "historical linguistics", in which the former would only handle structural linguistic data and the latter would consider the social (actually historical) issues in explaining linguistic change. The generative model, as a mentalist theory, has been classified as an asocial (hence diachronic) theory of linguistic change. The aim of this article is precisely to show that when the generative grammar starts to look at linguistic change and assumes language acquisition as the central place of linguistic change, it automatically becomes a social and historical approach of linguistic change and must necessarily be included in what is called "historical linguistics".

\section{Resumo}

Comumente se faz a distinção entre "linguística diacrônica" e "linguística histórica", na qual a primeira apenas manejaria os dados linguísticos estruturais e a segunda incluiria a questão social (efetivamente histórica) na explicação da mudança linguística. O modelo gerativista, por ser uma teoria mentalista, tem sido classificado como uma teoria associal (portanto diacrônica) da mudança linguística. O objetivo deste artigo é justamente mostrar que, quando o modelo gerativista passa a se preocupar com a mudança linguística e assume a aquisição da linguagem como o lugar central da mudança linguística, automaticamente se enquadra como um modelo social e histórico da mudança linguística, devendo necessariamente estar incluído no que se chama "linguística histórica".

\section{Entradas para indexação}

KEYWORDS: Linguistic Theory. Generative Grammar. Linguistic Change.

PALAVRAS CHAVE: Teorias Linguísticas. Gramática Gerativa. Mudança Linguística.

\section{Texto integral}

\section{APRESENTANDO 0 PROBLEMA}

Fazendo uma retrospectiva sobre a linguística histórica no Brasil, sobre seus fluxos e refluxos, Mattos e Silva (1988, 1999) assenta alguns conceitos muito importantes que guiam o seu entendimento sobre o que significa a linguística histórica. A partir da dicotomia saussureana entre sincronia e diacronia, pareceu haver uma grande distinção e abismo entre a linguística teórica e a linguística histórica. No entanto, a autora, retomando citações de Ferdinand de Sausurre e Noam Chomsky ${ }^{1}$, acertadamente sinaliza que ambas as perspectivas são as duas faces da mesma moeda: 
Devo destacar aqui que os fatos estudados pela Lingüística Histórica se apresentam como necessários aos argumentos da Lingüística Teórica, da mesma forma que a Lingüística Histórica, para ter caráter científico deve integrar-se em alguma vertente teórica e metodológica da Lingüística. Esse entrelaçar-se das duas Lingüísticas, assim delimitadas, refletem apenas, a meu ver, a natureza psico-biológica e sócio-histórica do objeto da Lingüística considerada na sua totalidade. (MATTOS E SILVA, 1988, p. 88)

A partir dessa primeira diferenciação, Mattos e Silva $(1988,1999)$ distingue linguística histórica stricto sensu e linguística histórica lato sensu, que, de maneira resumida, podem ser definidas, a primeira como o estudo das mudanças linguísticas propriamente ditas e a segunda como o estudo de dados linguísticos datados e localizados. Assim, por um lado, o estudo de por que um determinado aspecto de uma determinada língua funcionava de uma maneira numa determinada época mas funciona de outra maneira em outra época seria localizado na linguística histórica stricto sensu e, por outro, o estudo do funcionamento de uma língua em um determinado momento ou lugar seria localizado na linguística histórica lato sensu.

Mattos e Silva (1999) ainda traz à tona uma distinção muito importante: a diferença entre linguística histórica e linguística diacrônica, sinalizando que há um uso quase sinonímico entre história e diacronia nos estudos linguísticos, mas que os termos não devem ser considerados efetivamente sinônimos. A conceituação teórica proposta pela autora termina da seguinte maneira:

Para sintetizar e concluir essas breves reflexões sobre alguns conceitos preliminares, cumpre reafirmar que considerarei no desenrolar deste texto os conceitos de Lingüística Histórica lato sensu, que inclui descrições e interpretações sincrônicas datadas e localizadas, Lingüística Histórica stricto sensu, que se concentra na mudança lingüística no tempo, levando em consideração fatores intralingüísticos ou estruturais e fatores extralingüísticos ou sócio-históricos e Lingüística Diacrônica, que, tratando da mudança no tempo, se concentra no sistema ou na gramática, depreensões teóricas que subjazem às línguas históricas. (MATTOS E SILVA, 1999, p. 151)²

Ainda nesse contexto da retrospectiva sobre linguística histórica no Brasil, Mattos e Silva (1999) comenta que o gerativismo era, até aquele momento, uma das teorias mais proeminentes e traz algumas reflexões sobre como os estudos gerativistas se enquadram na linguística histórica, especialmente a partir dos anos oitenta, quando, com o modelo de Princípios e Parâmetros (CHOMSKY, 1981, 1986a), passam a olhar para sincronias passadas para buscar argumentos para o modelo teórico atraente de uma Gramática Universal constituída por princípios invariáveis e parâmetros abertos à variação (o que, de fato, diferenciaria as línguas humanas, pelo menos do ponto de vista gramatical $^{3}$ ). 
Sobre o chamado gerativismo diacrônico (MATTOS E SILVA, 1988, p. 109), Mattos e Silva (1999, p. 150) diz que "tanto os modelos diacrônicos dos estruturalismos, como os modelos diacrônicos dos gerativismos são, de fato, ahistóricos, porque excluem os fatores sócio-políticos, enfim históricos, na compreensão da questão central da mudança lingüística". Na perspectiva traçada por Mattos e Silva (1999), o interesse histórico (devendo ser lido como diacrônico) do gerativismo reside na busca de evidências para a fixação de parâmetros e caracterização da língua-I4 .

Na mesma linha de pensamento de Mattos e Silva (1999), considerando a pesquisa diacrônica no quadro gerativista como a-histórica, se posiciona Faraco (2005), quando diz:

Não é difícil para o leitor perceber (comparando Kiparsky com Martinet, por exemplo) que essa forma de tratar a mudança dá apenas uma roupa nova (os fatos são agora apresentados por regras) à forma estruturalista de analisar os eventos da história duma língua. Poderíamos ir até mais longe e dizer que, no fundo, o que vemos aí são as velhas leis fonéticas dos neogramáticos reaparecendo numa forma notacional diferente. (FARACO, 2005, p. 166)

O pensamento gerativista em diacronia se identifica, portanto, plenamente com a tradição forte em lingüística de considerar as mudanças como condicionadas por forças internas à língua. Retorna-se assim à perspectiva estruturalista [...] os gerativistas falam nas mudanças como submetidas aos princípios restritivos da gramática universal. A diferença é a hipótese inatista (o biologismo) destes que não estava naqueles. (FARACO, 2005, p. 168-169)

As falas de Mattos e Silva (1999) e Faraco (2005) sobre os estudos diacrônicos no modelo gerativista têm tido muito eco na discussão sobre linguística histórica no Brasil, fazendo com que pesquisadores insistam no discurso de que o gerativismo é uma teoria associal e a-histórica. De fato o é quando entendido no âmbito da linguística teórica. Contudo, uma nova perspectiva deve ser trazida quando o modelo gerativista passa a estudar as mudanças pelas quais as línguas passam ao longo do tempo ${ }^{5}$. Assim, nosso objetivo neste texto é mostrar que ambos os autores estão equivocados (cada um por uma razão diferente) e evidenciar que o modelo gerativista pode (e deve!) ser localizado nos estudos históricos e não meramente ${ }^{6}$ diacrônicos quando discute a questão da mudança linguística.

Com relação a Mattos e Silva (1999), cremos que a localização do gerativismo entre os modelos a-históricos se deve ao fato de que inicialmente, por questões empíricas e teóricas, os estudos gerativistas (como os citados pela autora: ROBERTS e KATO, 1993; BATTYE e ROBERTS, 1995) estavam preocupados com a descrição e funcionamento das línguas em diferentes etapas. Isso se explica (a) empiricamente porque, antes de explicar a mudança linguística, é preciso 
descrever as diferenças entre as etapas da língua e (b) teoricamente porque se estava principalmente em busca da caracterização das propriedades da Gramática Universal (e nesse sentido línguas passadas são da mesma natureza que as línguas atuais) ${ }^{7}$. Contudo, essa perspectiva já foi superada e os trabalhos avançaram nas explicações para a questão da mudança, uma vez que boas descrições e explicações do funcionamento das línguas-I passadas já foram feitas ${ }^{8}$.

Com relação a Faraco (2005), acreditamos que a localização do gerativismo entre os modelos a-históricos, sugerindo que o gerativismo se compare aos neogramáticos, se deve a uma má compreensão (pelo menos é o que se depreende da leitura do texto) do que seja Gramática Universal, princípios, parâmetros e aquisição da linguagem. Como mostraremos adiante, o biologismo do gerativismo muda completamente a perspectiva de estudos em linguística deslocando o objeto de estudo de fora para dentro da mente humana (cf. CHOMSKY, 1997). Uma vez que a língua, para o gerativista, só tem existência na mente e só é adquirida a partir da interação com o ambiente linguístico, é totalmente descabida a comparação com os neogramáticos, que acreditavam que a língua tinha existência e autonomia próprias.

Para alcançar nosso objetivo, seguimos o percurso a seguir. Na segunda parte, discutimos o giro de perspectiva de estudos da linguagem proposto pelo gerativismo no âmbito da Segunda Revolução Cognitiva, discorremos sobre como o gerativismo entende a aquisição da linguagem e apresentamos os conceitos de língua propostos no âmbito dessa perspectiva teórica. Na terceira parte, discorremos sobre como a mudança linguística é compreendida no modelo gerativista. Na quarta parte, discorremos sobre como essa perspectiva se coloca, efetivamente, como uma perspectiva histórica e não meramente diacrônica dos estudos linguísticos. Por fim, tecemos algumas considerações gerais, indicando como alguns trabalhos têm atuado no sentido de colocar o gerativismo no âmbito da Linguística Histórica.

\section{ALGUNS FUNDAMENTOS DA GRAMÁTICA GERATIVA}

Nesta seção, temos o objetivo de esclarecer alguns aspectos importantes da teoria gerativista que ainda parecem nebulosos e circulam de maneira bastante equivocada entre muitos dos não gerativistas. Deter-nos-emos ao máximo às palavras do próprio Chomsky, uma vez que é muito comum a apresentação de propostas do autor por meio de citações indiretas, o que representa um erro metodológico bastante grave.

Dessa forma, será possível compreender alguns posicionamentos iniciais adotados por autores gerativistas que trabalharam com linguística histórica. 


\section{A LÍNGUA COMO UM FENÔMENO COMPLEXO}

A primeira questão a ser esclarecida trata da concepção que Noam Chomsky tem de língua. Em Chomsky (1997), o autor dá a seguinte resposta:

Para poder prosseguir, deveríamos colocar com maior clareza o que entendemos por "uma língua". Tem havido muita controvérsia apaixonada a respeito da resposta correta para esta pergunta, e, de maneira mais geral, para a pergunta sobre como deveriam ser estudadas as línguas. A controvérsia não tem razão de ser, porque a resposta correta não existe. Se tivermos interesse em compreender como se comunicam as abelhas, tentaremos apreender algo sobre a natureza interna das abelhas, suas organizações sociais, e seu meio ambiente físico. Estas abordagens não são conflitantes; são reciprocamente comprovantes. 0 mesmo se dá com o estudo da linguagem humana: pode ser investigado de um ponto de vista biológico, e de inúmeros outros: o sóciolingüístico, o de língua e cultura, o histórico e assim por diante. Cada uma dessas abordagens define o objeto de sua investigação sob a luz de seus próprios interesses; e, se for racional, cada uma tentará apreender o que puder do que vem das outras abordagens. Por que razão estas são matérias que despertam muita paixão no estudo dos seres humanos seja talvez uma pergunta interessante, mas por ora vou pô-la de lado. (CHOMSKY, 1997, p. 51-52)

A partir da citação acima, fica claro que, para Noam Chomsky, a língua é um fenômeno humano, sendo, portanto, complexo, que pode ser estudado a partir de diferentes perspectivas, não existindo uma perspectiva melhor ou mais correta. Pelo contrário, Chomsky (1997) deixa claro que é bastante útil e interessante aproveitar das demais teorias aquilo que for útil para a teoria com a qual se trabalha9.

Nesse sentido, vale a pena retomar as palavras de Guimarães e Orlandi (2006), quando debatem o conhecimento sobre a linguagem:

Pelo que aqui ficou exposto podemos ver que há uma relação intrínseca e constitutiva entre teoria/método/objeto, nos estudos da linguagem. Assim é que, em ciência da linguagem, o objeto língua é determinado pela teoria e o método que a pressupõem. Mais do que isso, deve haver uma relação necessária entre teoria e método na determinação de seu objeto. (GUIMARÃES e ORLANDI, 2006, p. 151) 
As citações de Chomsky (1997) e Guimarães e Orlandi (2006) levam à conclusão de que tentativas de conceituar a língua são infrutíferas, dado que se trata de um fenômeno multifacetado. Em qualquer caso, o estudo sobre a língua será restrito, uma vez que feito sob uma perspectiva específica.

Pode-se destacar, portanto, que Chomsky (1997) reconhece a complexidade do fenômeno linguístico, a multiplicidade de perspectivas de estudo, mas, tendo em vista a perspectiva teórica adotada para abordar o fenômeno da linguagem humana, escolhe somente alguns aspectos para aprofundamento.

\section{A PERSPECTIVA COGNITIVISTA DO ESTUDO DA LINGUAGEM}

Uma vez explicitado que não existe maneira correta para se estudar a linguagem humana dado que a linguagem humana é um fenômeno complexo, pode ser apresentada a perspectiva com a qual a gramática gerativa trabalha.

Desde Chomsky (1957), fica claro que o objeto de estudo da gramática gerativa é a sintaxe, definida pelo autor como "o estudo dos princípios e processos pelos quais sentenças são construídas em línguas particulares" (CHOMSKY, 1957, p. 11). A questão é retomada por Chomsky (1965), quando mostra que nem a gramática tradicional nem o estruturalismo puderam construir teorias sintáticas. A gramática tradicional, por um lado, se concentrou nas partes da oração, desenvolvendo muito mais um trabalho classificatório/taxionômico. 0 estruturalismo, por outro lado, se deteve na discussão do signo linguístico e no nível fonológico como sistema. Para ilustrar a questão, Chomsky (1965, p. 22) traz os seguintes exemplos:

a. I persuaded John to leave.

"Eu convenci John a sair"

b. I expected John to leave.

"Eu esperava que John fosse embora"

Embora as duas frases em (1) tenham a mesma ordem linear (SN-V-SN-P-V) e possam receber a mesma classificação interna (sendo compostas por uma oração matriz e uma oração subordinada), ambas devem receber estruturas diferentes considerando o contraste entre (2) e (3) abaixo:

(2) a. Eu convenci João a ser examinado pelo médico.

b. Eu convenci o médico a examinar João. 
(3) a. Eu esperava que João fosse examinado pelo médico.

b. Eu esperava que o médico examinasse João.

As orações em (2) têm, cognitivamente, a mesma interpretação, mas as orações em (3) não. Segundo Chomsky (1965), nenhuma gramática do inglês havia, até então, observado essa diferença.

Chomsky (1965) postula que qualquer falante de qualquer língua tem um conhecimento intuitivo sobre sua língua. Esse conhecimento não é algo que possa ser, necessariamente, explicitado. 0 falante sabe usar a língua mas pode não saber dizer como faz esse uso. Assim, é proposto que o falante tenha uma competência linguística, que se opõe ao desempenho ou performance, que é o uso que o falante faz de sua competência.

Ao trazer a discussão para os conhecimentos que o falante nativo tem intuitivamente, Chomsky (1965) insere a sua perspectiva dos estudos linguísticos no âmbito das ciências cognitivas, deslocando a investigação dos produtos para os processos:

\begin{abstract}
A gramática gerativa teve origem no contexto do que muitas vezes é chamado de "a revolução cognitiva" dos anos 50, e foi um fator importante no desenvolvimento dela. Seja ou não apropriado o termo "revolução", aconteceu uma mudança de perspectiva importante: do estudo do comportamento e seus "produtos " (textos, por exemplo) para os mecanismos internos que entram em jogo no pensamento e na ação. (CHOMSKY, 1997, p. 52)
\end{abstract}

A pergunta crucial é: como o ser humano aprende tanto em tão pouco tempo? Essa questão, conhecida como Problema de Platão, é o ponto central dentro do quadro teórico da gramática gerativa ${ }^{10}$.

A aquisição da linguagem é entendida, portanto, como o resultado da interação dos princípios da faculdade da linguagem com o ambiente linguístico ao qual a criança foi exposta, como se ilustra na representação a seguir:

(4) Dados Linguísticos Primários ----> Gramática Universal ----> Gramática Particular (no período de aquisição)

A representação acima significa que a criança ouve os dados linguísticos primários (o input) e, guiada pela faculdade da linguagem, atinge um estágio estável da competência linguística em conformidade com o input que recebeu. Os princípios são universais e, portanto, somente as propriedades do léxico e os parâmetros precisam ser adquiridos. 
Diante desses fatos e fazendo uma relação com outros órgãos do corpo humano, Chomsky (1975) conclui que os seres humanos nascem com um órgão específico para a linguagem e que, com relação ao aspecto estrutural da linguagem, o homem só aprende aquilo que já está programado geneticamente para aprender ${ }^{11}$. Esse é um aspecto importante do pensamento chomskyano e sobre o qual tem havido muita confusão: a teoria gerativa defende que uma parte do conhecimento linguístico seja inata e não que todo ele o seja ${ }^{12}$. Em outras palavras, a teoria gerativa defende que a capacidade de aquisição de uma língua na infância é devida a uma característica genética, que os princípios que regem a aquisição são pré-existentes na mente humana e que o aspecto estrutural da linguagem, ou seja, as possibilidades da estrutura gramatical das línguas, é codificado geneticamente. Isso não significa que o convívio social não seja importante ou mesmo determinante no processo de aquisição da linguagem. O convívio social e a exposição a um input são necessários para que essas possibilidades inatas sejam restringidas e a criança adquira sua primeira língua. Caso contrário, se tal exposição não fosse necessária e todo conhecimento fosse dado geneticamente, deveria ser esperado que as crianças já nascessem falando uma língua específica e que todo mundo falasse a mesma língua ou que as pessoas em uma comunidade linguística falassem línguas aleatórias. No entanto, o que se comprova empiricamente é que há uma certa homogeneidade (que não deve ser entendida como total igualdade) na língua falada por pessoas de uma mesma comunidade linguística.

Em suma, o modelo gerativista quer entender o que existe na mente do ser humano que faz com que todo e qualquer ser humano (a menos que seja privado da interação ou tenha alguma patologia de linguagem) e apenas esta espécie seja capaz de adquirir uma língua ${ }^{13}$. Essa perspectiva, no entanto, não nega as demais. Pelo contrário, apenas delimita seu escopo.

\section{AS VÁRIAS DEFINIÇÕES DE LÍNGUA}

Uma vez que a linguística é uma ciência e opera com modelos teóricos, seus conceitos precisam estar muito bem definidos. Por essa razão, Chomsky (1986a) traz uma reflexão sobre os diferentes conceitos de língua, partindo da perspectiva do senso comum para chegar nas perspectivas científicas, que, segundo o autor, precisam abandonar a noção de língua do senso comum.

Chomsky (1986a) indica a noção de língua do senso comum está carregada de valores sociopolíticos e aponta, por exemplo, que se fala do chinês como uma língua mesmo que vários dos seus dialetos sejam tão diversos como as línguas românicas e se fala do alemão e do holandês como línguas diferentes mesmo que vários de seus dialetos sejam mutuamente inteligíveis. Essa noção sociopolítica de língua remete à constituição dos Estados-Nação. Chomsky (1986a, p. 15) recupera a frase de Max Weinreich, segundo a qual a língua é um dialeto com um exército e uma esquadra. Observe-se que essa perspectiva é a que aparece nas gramáticas tradicionais e, como bem sinaliza Gauger (1997), as gramáticas tradicionais não 
constituem uma atividade científica. Nesse sentido, Chomsky (1986a) diz que todas as perspectivas científicas de língua devem abandonar a noção do senso comum.

A partir dessa discussão preliminar sobre o conceito de língua do senso comum, Chomsky (1986a) introduz dois conceitos científicos de língua: língua-E e língua-I.

A primeira noção científica de língua (língua-E) é apresentada quando Chomsky (1986a) relata que linguistas estruturalistas e descritivistas tenderam a ver a língua como uma coleção de ações, enunciados ou formas linguísticas associadas a um significado destacando que, para Ferdinand de Saussure, uma língua era um sistema de sons associado a um sistema de $\operatorname{conceitos}^{14}$, e que, para Leonard Bloomfield, uma língua é "a totalidade de enunciados que podem ser produzidos numa comunidade linguística" (CHOMSKY, 1986a, p. 19. tradução nossa). 0 autor define então esses conceitos como compatíveis com uma noção de língua-E (língua externa) no sentido de que essas construções são entendidas independentemente das propriedades da mente/cérebro. A língua-E seria, assim, na nomenclatura de Chomsky (1997) citada acima, os produtos, ou seja, os resultados, os dados visíveis: a sequência de sons.

A segunda noção científica de língua é elaborada a partir de uma observação de Otto Jespersen, que propôs que havia uma noção de estrutura na mente do falante, que o guia na produção de sentenças, levando Chomsky (1986a) a caracterizar essa noção de estrutura como língua-I (língua interna):

A língua-I é, assim, algum elemento da mente da pessoa que conhece a língua, adquirido pelo aprendiz e usado pelo falanteouvinte.

Considerando a língua como língua-I, a gramática poderia ser, então, uma teoria da língua-I, que é o objeto sob investigação. (CHOMSKY, 1986a, p. 22. tradução nossa)

Para ilustrar a diferença entre língua-E e língua-I, observe-se o dado em (5):

O João disse que ele virá mais tarde.

Essa sentença é possível tanto em português brasileiro como em português europeu. Portanto, as duas variedades do português constituiriam a mesma língua$E$ (caso somente essa sentença estivesse em causa). No entanto, o falante brasileiro e o falante português não produzem e interpretam essa mesma sentença da mesma forma: "ele" pode se referir a João para o brasileiro, mas se refere a outra pessoa para o português, o que indica, como diversos trabalhos já mostraram (cf. GALVES, 2001), que brasileiros e portugueses têm línguas-I diferentes. 
Essa distinção entre língua-E e língua-I se torna crucial quando se pretende investigar o que existe na mente dos seres humanos no sentido de que falantes de variedades diferentes da mesma língua podem ter conhecimentos diferentes sobre como construir orações em cada uma das variedades. Além disso, deixa manifesta a mudança de perspectiva proposta na linguística gerativa: deixando de lado os produtos (dados) para concentrar-se nos mecanismos mentais que geram tais produtos.

\section{A MUDANÇA LINGUÍSTICA NO QUADRO GERATIVISTA15}

A discussão acima indicou que a criança tem um dispositivo mental, específico da espécie humana, que a guia no processo de aquisição da linguagem a partir da interação com o ambiente em que vive. Observe-se o esquema em (6):

(6)

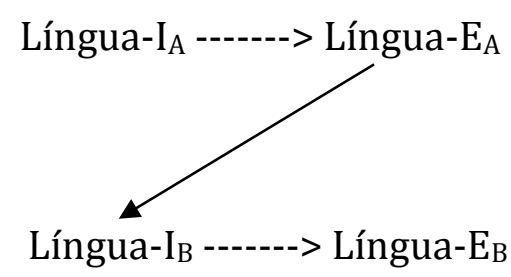

0 esquema em (6) mostra que uma língua-I (o conhecimento mental do indivíduo) gera uma língua- $E$, que vai ser o input para a criança. A partir desse input, a criança vai construir uma língua-I que vai gerar uma língua-E; sendo que, essas duas últimas, em tese, deveriam ser idênticas às línguas da geração anterior. E assim por diante.

Esse modelo, à primeira vista, sugere uma hipótese forte: as línguas não mudariam nunca, já que o output (a gramática da criança) seria necessariamente convergente com o input (a gramática do adulto). No entanto, o que mundo real mostra é justamente o contrário: as línguas passam por mudanças ${ }^{16}$, chegando ao que Roberts e Roussou (2003) chamaram de o problema lógico da mudança linguística, que deve ser entendido da seguinte forma: se a criança constrói sua gramática de acordo com os dados linguísticos primários, ou seja, o que ouve dos adultos, por que as línguas mudam?

Nas subseções a seguir, considerando o modelo de Princípios e Parâmetros ${ }^{17}$, explicitaremos como o modelo gerativista resolve o problema lógico da mudança linguística e, em seguida, discutiremos como essa questão se insere, obrigatoriamente, no quadro social dos estudos da língua. 
Lightfoot (1991) propõe, então, um modelo que toma da mudança linguística argumentos para explicar como a criança fixa os parâmetros ${ }^{18}$. A tese central de Lightfoot (1991) é que o gatilho para a experiência da criança é constituído por elementos robustos, que são estruturalmente simples e que a criança não é sensível nem a material de domínios subordinados ${ }^{19}$ nem a evidência negativa. A motivação para tal ideia é que a criança, no seu processo de desenvolvimento da linguagem, é seletiva na consideração dos dados que levará em conta para construir sua gramática mental, o que é compatível com a ideia de limitar essa busca por os contextos matrizes.

Para mostrar que a criança não é sensível a material de domínios subordinados, Lightfoot (1991) traz dados comparativos de diversas línguas em que as diferenças na realização de materiais subordinados podem ser, efetivamente, depreendidas pelo material presente na oração matriz. Para ilustrar, mencionaremos o contraste entre o inglês e o holandês com relação ao movimento de elementos interrogativos por cima do complementizador que introduz a oração subordinada. Observem-se primeiro os dados do inglês em (7), adaptados a seguir de Lightfoot (1991, p. 29):

\author{
a. Who ${ }_{i}$ did Jay say [e $e_{i}$ that Kay saw $e_{i}$ ] \\ quem fez Jay dizer que Kay viu \\ "Quem Jay disse que Kay viu" \\ b. *Who did Jay say [ $\mathrm{e}_{\mathrm{i}}$ that $\mathrm{e}_{\mathrm{i}}$ saw Kay] \\ quem fez Jay dizer que viu Kay \\ "Quem Jay disse que viu Kay" \\ c. Whoi did Jay say [e $e_{i} e_{i}$ saw Kay] \\ quem fez Jay dizer viu Kay \\ "Quem Jay disse (que) viu Kay"
}

No modelo teórico adotado por Lightfoot (1991), a agramaticalidade de uma sentença podia se dever à falta de regência (posição antecedente) de uma categoria vazia (marcada com e(mpty) nos exemplos). Isto, combinado com a ideia de que o movimento tem de fazer uma parada na borda de um domínio subordinado ${ }^{20}$, resulta numa restrição ao movimento de "who". Enquanto objeto, ele pode se mover, mas, enquanto sujeito, só pode realizar esse movimento se o complementizador "that" estiver ausente, daí a inaceitabilidade de (7b). A 
explicação técnica é que o segundo "e $\mathrm{e}$ ", a posição de base do sujeito em (7b), não seria regida, por causa do bloqueio de uma posição interveniente, no caso, "that".

Por outro lado, o dado do holandês em (8), também adaptado de Lightfoot (1991, p. 29), mostra que o sujeito interrogativo "wie" pode passar por cima do complementizador "dat":

(8) Wie $e_{i}$ denk je $\left[e_{i}\right.$ dat $e_{i}$ het boek gelezen had]

quem $_{i}$ acha você que $e_{i}$ esse livro lido tem

"Quem você acha que tem lido esse livro?"

A diferença é que o próprio elemento "dat" seria capaz de reger a categoria vazia onde é gerado o sujeito "wie". Apesar de aparentemente arbitrária, essa explicação tem uma motivação, que tem a ver com o fato de o holandês, mas não o inglês, ser uma língua V2.

Línguas V2 são, muito grosso modo, aquele grupo de línguas em que o verbo finito aparece em segunda posição precedido apenas por um constituinte qualquer independente de sua função sintática ou papel temático (cf. HAIDER e PRINZHORN, 1986, DEN BESTEN, 1989; VIKNER 1995). As línguas germânicas atuais, exceto o inglês, fazem parte desse grupo ${ }^{21-22}$. Por ser uma língua $V 2$, o holandês exige que o verbo flexionado ocupe a segunda posição na oração, não impedindo que a categoria vazia na posição de sujeito seja regida pelo pronome interrogativo wie na periferia esquerda, uma exigência do modelo teórico nessa época. Portanto, na realidade a diferença entre as orações subordinadas do inglês e do holandês pode ser reduzida a diferenças nas orações matrizes nas respectivas línguas, considerando-se os exemplos em (9), do holandês, e (10), do inglês, a seguir, adaptados de Lightfoot (1991, p. 29-30):

(9) Wie heeft $_{j} e_{i}$ het boek gelezen $e_{j}$

Quem tem o livro lido

"Quem tem lido o livro"

(10) a. who $e_{i}$ has read the book

quem tem lido o livro

"Quem leu o livro"

b. *whoi didj ei ej read the book

quem PASSADO ler o livro 


\author{
"Quem leu o livro" \\ c. what $\operatorname{did}_{j}$ Jay $e_{j}$ read $e_{i}$ \\ o que teve Jay lido \\ "O que Jay leu"
}

Note-se que o inglês, por não ser uma língua V2, não possui construções como a de (9). Em (10a) o verbo "has" não se moveu para uma posição mais alta, como no holandês, dado que o inglês não é uma língua $V 2$ e nem tem a ordem $0-\mathrm{V}$. 0 dado em (10b) é esclarecedor porque, sendo agramatical, mostra que o verbo auxiliar não pode ocorrer nesse tipo de construção em que o interrogativo é o sujeito porque bloqueia a regência da categoria vazia, diferentemente do que ocorre em (10c), onde o auxiliar é possível porque o interrogativo é o objeto e a categoria vazia é regida pelo verbo ${ }^{23}$.

O contraste entre o holandês e o inglês discutido acima é argumento, para Lightfoot (1991), de que a criança é aprendiz de grau-0, ou seja, que é sensível apenas ao material de domínios matrizes. 0 que acontece no domínio encaixado é consequência do que acontece no domínio matriz, isto é, a criança aprendiz de inglês não aprende fenômenos como o que aparece em (7), mas sim o que se discute em (10); dessa forma, o que acontece em (7) é uma consequência de a criança ter aprendido o que acontece em (10).

A partir desse referencial, Lighfoot (1991) demonstrará como a mudança linguística opera a partir da fixação de parâmetros, considerando dados da história do inglês ${ }^{24}$.

\title{
A AQUISIÇÃO DA LINGUAGEM COMO O PONTO CENTRAL DA MUDANÇA LINGUÍSTICA
}

Uma vez mais: o modelo gerativista aborda o estudo da linguagem numa perspectiva cognitivista/mentalista. Essa perspectiva traz várias implicações: a) a língua não é mais vista como uma entidade fora do ser humano com autonomia própria, como proposto no estruturalismo. A língua, nessa perspectiva, só tem existência na mente/cérebro humana; b) a mudança linguística, nessa perspectiva, é compreendida não como alterações na língua (no sistema) ao longo do tempo, mas, pelo contrário, como substituições sucessivas de gramáticas (línguas-l) ao longo das gerações. A sucessiva substituição de gramáticas dá a impressão de continuidade porque as línguas-E são contínuas; c) a aquisição da linguagem se torna o lugar central das mudanças linguísticas.

0 ponto que agora precisa ser explicado, como já mencionamos anteriormente, é como as línguas mudam (ou, nos termos mais adequados para o modelo gerativista, como as gramáticas são substituídas) se a aquisição da linguagem deve ser convergente com o input que a criança recebeu. Nesse sentido, 
Lightfoot (1991) traz uma interessante discussão sobre a questão, ilustrando-a com diversos aspectos da história do inglês, e mostra que, para que a língua-I construída pela criança seja diferente da língua-I do adulto, alguma coisa deve ter acontecido na língua- $E$ do adulto, que serviu de input para a criança. Lembre-se que a criança não acessa a língua-I da geração anterior porque a língua-I é algo interno à mente. A criança constrói sua língua-I a partir da análise do que ouve, ou seja, da língua- $E$, o que tem impacto no fato de a criança não ter fixado os parâmetros de sua gramática mental da mesma forma que a geração anterior ${ }^{25}$.

Para ilustrar a proposta de que a aquisição da linguagem é o lugar da mudança linguística, Lightfoot (1991) discute dados da história do inglês, dos quais sintetizaremos a argumentação da mudança da ordem $\mathrm{O}-\mathrm{V}$ para $\mathrm{V}-\mathrm{O}$. Lightfoot (1991) comenta que o inglês antigo, assim como o alemão e o holandês atuais, era uma língua V2 assimétrica (o verbo aparece em segunda posição em orações matrizes mas aparece em posição final em orações subordinadas) e que a criança, como aprendiz de grau-0, depreende apenas dos domínios matrizes as evidências para o movimento do verbo para uma posição mais alta na oração ${ }^{26}$. 0 autor dá três evidências do movimento do verbo em orações matrizes em holandês (dados de LIGHTFOOT, 1991, p. 52-54):

(11) in Utrecht vonden de mensen bet idee gek

em Utrecht acharam as pessoas a ideia louca

"As pessoas em Utrecht acharam a ideia louca."

(12) Jan belt de hoogleraar op

Jan chamou o professor PART

"Jan telefonou para o professor."

(13) Jan loopt niet

Jan anda não

"Jan não anda."

Em (11), há algum elemento, no caso, o sujeito "de mensen", intervindo entre o verbo e o objeto. Em (12), o verbo se separa da partícula "op". Em (13), a negação "niet" segue o verbo. Enquanto especialmente (12) indica o movimento do verbo a partir da posição final da frase, (11) e (13) sugerem que esse movimento tem como alvo uma posição mais alta que o domínio oracional padrão, que inclui o sujeito, assim como elementos flexionais, como os indicativos de polaridade e tempo da oração. 
Uma quarta evidência de que a ordem subjacente é $\mathrm{O}-\mathrm{V}$ é dada por construções matrizes com verbo no infinitivo (exemplo extraído de LIGHTFOOT, 1991, p. 55):

(14) Jantje koekje hebben?27

Jantje bolo ter

"Jantje ter bolo?"

A conclusão da discussão é que, com base nesses dados, a criança não precisaria observar o material subordinado, que manifesta superficialmente a ordem $\mathrm{O}-\mathrm{V}$, dado que, a partir do material do domínio matriz, a criança já saberia que houve um movimento do verbo para a esquerda. Muito interessante nesse sentido é o exemplo em (12), no qual a partícula segue o objeto, o que evidencia que, no ordenamento básico da frase, a ordem é $0-V$, apesar, de nesse caso, o ordenamento superficial (final) ser V-O.

A partir daí o autor passa a analisar a história do inglês, mostrando como a aquisição da linguagem (especialmente a observação de material matriz) vai ser responsável pela mudança da ordem $\mathrm{O}-\mathrm{V}$ para V-O. Seguindo a linha de pensamento já apontada anteriormente, as propriedades gramaticais de fases antigas das línguas podem ser idênticas às propriedades encontradas em alguma língua na atualidade, o que se torna, por conseguinte, o ponto de partida da análise de que as gramáticas são do mesmo tipo. Nesse sentido, apesar de elencar quatro diferenças entre o inglês antigo, por um lado, e o alemão e o holandês, por outro, Lightfoot (1991) enfatiza que as demais propriedades sugerem que o inglês antigo também tenha sido uma língua com ordem $\mathrm{O}-\mathrm{V}$ subjacente, como se observa através dos dados em (15):

(15) a. ond pa ahof Drihten hie up

e PART levou Deus eles para.cima

“e então Deus levantou-os” (Blicking Homilies 157.22)

b. paet he ðone cwelmbæran hlaf aweg bære

que ele o mortal pão para.longe carregou

"que ele carregou o pão mortal para longe"

(Homilies of the Anglo-Saxon Church II, 162, 23)

(LIGHTFOOT, 1991, p. 61) 
Em (15a), a partícula "up" aparece separada do verbo "ahof", tendo o sujeito "Drihten" entre os dois. Em (15b), o verbo "bære" e a partícula aweg" aparecem juntos.

Lightfoot (1991) argumenta que, embora a ordem O-V fosse consistente nas orações subordinadas, não o era nas orações matrizes, o que limita a robustez dos dados; isso, em última análise, leva a criança a efetuar a mudança para a ordem V0. Lightfoot (1991, p. 64-65) ainda evidencia que as orações matrizes do inglês antigo possuíam quatro ordens variantes, que não ofereciam evidências para a criança de que o verbo havia se movido, nem que a ordem subjacente era $0-\mathrm{V}$ :
a. sujeito-X-verbo
b. objeto-sujeito-verbo
c. sujeito-X-verbo-X
d. sintagma adverbial-sujeito-verbo

Por outro lado, houve, também, segundo Lightfoot (1991, p. 65-66), uma mudança gramatical que pareceu neutralizar a falta de evidências gerada a partir de dados dos tipos indicados em (16): os morfemas presos prefixados aos verbos, que se moviam juntamente com o verbo, passaram a se comportar como partícula, aparecendo separadamente do verbo, o que, de alguma forma, reforçava a ordem O-V subjacente.

Lighfoot (1991, p. 67) sintetiza a mudança gramatical do inglês da seguinte maneira: Em um primeiro momento, a ordem $\mathrm{O}-\mathrm{V}$ era robusta o suficiente em orações matrizes. Com o decréscimo ou obscurecimento da ordem $\mathrm{O}-\mathrm{V}$ devido ao aumento das construções em (16), as construções com partículas garantiam à criança a análise de que a ordem subjacente era $\mathrm{O}-\mathrm{V}$. Contudo, como a posição das partículas se tornou variável, diferentemente do que acontece com o holandês e o alemão atuais, num terceiro momento, as partículas deixaram de evitar os efeitos do decréscimo da ordem $\mathrm{O}-\mathrm{V}$ em orações matrizes, de modo que a ordem $\mathrm{O}-\mathrm{V}$ deixou de ser aprendida pela criança. Por fim, Lightfoot (1991) afirma que, a partir desse momento, a ordem V-O passou a ser o padrão em orações subordinadas também (o que reforça sua análise de que somente os domínios matrizes são "visíveis" para a criança na fixação paramétrica).

A discussão da mudança linguística apresentada até aqui tem um caráter ahistórico na medida em que coloca a aquisição da linguagem, que é guiada por alguma propriedade da mente/cérebro humano decorrente de uma dotação biológica específica da espécie, como responsável pela mudança linguística quando a criança não fixa os parâmetros de acordo com língua-I da geração anterior. Contudo, como salientado anteriormente, a fixação paramétrica é coerente com o input (língua-E) recebido. Observe-se que, na explicação de Lightfoot (1991), fica claro que, enquanto a criança tinha evidências para fixar o parâmetro da ordem 0 - 
V, o fazia corretamente. Quando, no entanto, deixa de ter evidências no ambiente linguístico, passa a fixar o parâmetro de acordo com o que observa.

Nesse ponto, é possível mostrar por que é equivocada a afirmação de Faraco (2005) de que o gerativismo é um "estruturalismo de roupa nova" e que faz as leis dos neogramáticos reaparecerem com outra notação. Por um lado, o estruturalismo entende a língua como um elemento orgânico e autônomo. A mudança linguística é entendida, assim, como uma reorganização do sistema já que cada peça só tem valor quando colocada em contraste com outra. Por outro lado, para os neogramáticos, que tinham como foco de estudo as mudanças sonoras, as leis fonéticas eram absolutamente regulares, não se concebendo exceções a elas. Ora, o gerativismo difere das duas visões, já que não necessariamente observa a mudança linguística a partir de uma perspectiva de mudança internamente motivada, ao contrário do que sugerem os modelos anteriores, quando aplicados a diferentes níveis de análise linguística. $\mathrm{Na}$ verdade, a mudança gramatical no quadro gerativista é, em último recurso, sempre externamente motivada, considerando a dependência dos dados da língua-E no momento da aquisição de língua pela criança.

A mudança linguística no modelo gerativista não tem direcionalidade, não tem força, não tem tendência, não tem deriva. A mudança linguística no quadro da gramática gerativa é explicada a partir da análise dos dados linguísticos feita pela criança durante o processo de aquisição. Uma vez que a criança precisa de exposição aos dados linguísticos para adquirir uma língua e só é exposta a eles se viver em sociedade, o problema da mudança paramétrica se torna, então, um problema social, aspecto que será discutido na próxima seção.

\section{A INSERÇÃO DO "GERATIVISMO DIACRÔNICO" NO QUADRO DA LINGUÍSTICA HISTÓRICA}

Até aqui, viemos discutindo, de modo muito geral, como a gramática gerativa compreende o funcionamento da linguagem humana a partir de uma perspectiva cognitivista/mentalista da linguagem humana. Ao colocar a aquisição da linguagem como o lugar central para a mudança linguística, especialmente para a mudança gramatical, o gerativismo mantém seu caráter cognitivista/mentalista dos estudos da linguagem. Contudo, abre uma porta de diálogo extremamente profícuo com as ciências sociais no sentido de compreender quais são os possíveis gatilhos para a mudança linguística e como ela acontece.

Nesta seção, discorreremos sobre como o modelo gerativista pode ser compreendido, efetivamente, como um modelo histórico (não meramente diacrônico) da mudança linguística, tomando como norte a afirmação de Paixão de Sousa (2004, p. 8): "Procuro lembrar aqui que mesmo para os estudos da mudança linguística no quadro gerativista - ou seja, nos estudos preocupados com a reconstituição das etapas gramaticais - a constituição histórica é relevante".

Um bom exemplo de como a questão social é relevante para a explicação das mudanças internas é trazido por Kroch (2001, p. 716-719) quando discute a perda 
do efeito V2 a partir da relação entre os dialetos do norte e os dialetos do sul da Inglaterra que, em certo momento, entraram em contato. Os dois dialetos do inglês possuíam a propriedade V2, porém, com características diferentes em relação à inversão dos sujeitos pronominais, Os falantes do norte tratavam sujeitos nominais e pronominais da mesma forma na ordem XP-V-S e os falantes do sul, de forma distinta, com inversão somente de elementos nominais, variando entre as ordens $\mathrm{XP}-\mathrm{V}-\mathrm{Snom}$ e XP-Spro-V. Esse fato fez os falantes do norte, ao entrarem em contato com falantes do sul, tacitamente interpretarem que os falantes do sul falavam uma língua com duas gramáticas em competição já que não havia distinção no tratamento de pronomes e sintagmas nominais plenos no dialeto do norte. Como um dos efeitos do contato de línguas e da koineização é a acomodação (ver TUTEN, $2003)^{28}$, os falantes do norte passaram a produzir estruturas não V2 porque era essa a interpretação que eles davam à ordem XP-Spro-V dos falantes do sul, o que, por sua vez, tornou obscura, para as crianças, a evidência de que a sua língua apresentava uma gramática $\mathrm{V} 2^{29}$.

\section{ALGUNS DESAFIOS PARA A PESQUISA HISTÓRICA}

Paixão de Sousa (2006) faz uma discussão sobre algumas questões gerais que afetam o que se conhece como linguística histórica, das quais destacaremos apenas duas. A primeira delas está relacionada com o fato de que, em qualquer pesquisa histórica, o pesquisador trabalha não com o plano dos acontecimentos mas com o plano dos registros. Isso quer dizer que, quando se faz qualquer pesquisa histórica, não se tem acesso direto aos fatos em si mas sim aos registros que foram feitos desses fatos. A segunda questão, ao nosso ver decorrente da primeira, está relacionada com o fato de a pesquisa histórica trabalhar com o que o tempo deixou. Isso implica que muitos dos fatos que aconteceram no passado não chegaram até os dias atuais por uma impossibilidade do tempo. A discussão pode ser sintetizada da seguinte forma:

No caso da documentação sobre as línguas, os dados históricos principais são os registros escritos que chegam até nós. Ora, esses registros representam um fragmento dos acontecimentos. Mais que isso: um fragmento daquilo que um determinado contexto histórico julgou relevante registrar; que um segundo momento histórico julgou importante preservar; e que um terceiro momento histórico considerou pertinente examinar. Trazendo esse problema mais para perto, isso significa que como documentação das línguas espanholas medievais temos acesso, hoje, aos fragmentos da língua escrita nas cortes cristãs - por exemplo, os códigos de leis e outros documentos legais; as crônicas históricas dos feitos dos reis cristãos. Importantes e interessantíssimos fatos lingüísticos nos são revelados por estes testemunhos; não podemos esquecer, entretanto, que há todo um 
universo de fatos lingüísticos contemporâneos a eles, e aos quais não temos acesso por meio de documentação - porque tais fatos nunca foram registrados. Não foram julgados dignos de registro
em sua época; ou não foram considerados dignos de preservação (PAIXÃO DE SOUSA, 2006, p. 36).

Ora, se a linguística histórica opera com o que o tempo deixou e o que o tempo deixou é apenas um fragmento do que aconteceu, qualquer perspectiva teórica em linguística histórica precisa, de alguma forma, estar atenta a essas contingências do tempo para caracterizar seu objeto.

No que interessa para a pesquisa histórica no quadro da gramática gerativa, o ponto crucial é depreender, como aponta Paixão de Sousa (2004), como a mudança gramatical (as substituições de línguas- $I$ ) acontece a partir das mudanças linguísticas registradas nos textos ${ }^{30}$. Uma vez que o material de trabalho de qualquer pesquisa histórica são os textos, mesmo numa perspectiva formalista, ter em mente as condições de produção desses textos é imperativo. Neste ponto, concordamos mais uma vez com Paixão de Sousa (2004, p. 18-19) quando diz: "[e]ntendo que um texto escrito será antes de tudo um objeto histórico (concreto, se quisermos), pois é produzido recebido preservado e investigado em circunstâncias historicamente construídas" (grifos da autora).

Por fim, desde a década de 1980, quando os primeiros trabalhos sobre mudança gramatical foram feitos no modelo gerativista, diversos autores, entre eles Adams (1987), sinalizaram que a pesquisa histórica (ou de sincronias passadas) se difere da pesquisa gramatical contemporânea pelo fato de que não é possível recorrer ao método experimental. 0 modelo gerativista trabalha com as noções de gramaticalidade e agramaticalidade e usa a noção de agramaticalidade para explicar as construções gramaticais recorrendo ao julgamento de falantes nativos. Essa metodologia para conhecimento da língua-I de falantes vivos não pode ser utilizada nas pesquisas históricas, evidentemente. Essa limitação dos dados deve ser trabalhada a partir de considerações metodológicas específicas ${ }^{31}$.

\section{A RELEVÂNCIA DO HISTÓRICO E DO SOCIAL PARA O "GERATIVISMO}

\section{DIACRÔNICO"}

Apontamos, anteriormente, que o modelo gerativista assume a aquisição da linguagem como o lugar central da mudança linguística devido a uma reconfiguração paramétrica diferente da geração anterior. Para que isso aconteça, tem sido unanimidade assumir que alguma mudança no ambiente linguístico aconteceu, não fornecendo pistas para a criança fixar os parâmetros da mesma forma que a geração anterior ${ }^{32}$. Se o objetivo dos estudos históricos no quadro da gramática gerativa é entender como a dinâmica da mudança gramatical acontece, uma pergunta que surge automaticamente é como o ambiente linguístico pode mudar de uma geração para outra de modo a alterar a configuração paramétrica entre as duas gerações. Essa pergunta coloca os estudos gerativistas no centro dos 
estudos históricos porque, para explicar em que condições o ambiente linguístico foi alterado, precisa entender a língua como um objeto histórico.

Tuten (2003), ao apresentar o modelo da sociolinguística histórica, comenta que, nos últimos anos, os sociolinguistas têm defendido que a língua não muda mas, pelo contrário, é mudada pelo falante. Segundo o autor, essa questão deveria ser óbvia. No entanto, a maneira como a língua foi tratada desde o século XIX dificultou essa compreensão, fazendo com que a participação do falante fosse amplamente ignorada nos estudos sobre mudança linguística. Considerando os cinco problemas da mudança linguística propostos por Weinreich, Labov e Herzog (1968), Tuten (2003) ressalta ainda que a perspectiva interna da mudança linguística tem trabalhado bem com o problema das restrições, mas deixa a desejar na explicação dos problemas da transmissão e da implementação: "Por que mudanças em traços estruturais acontecem em uma língua particular em um dado momento mas não em outras línguas com o mesmo traço ou na mesma língua em outro momento?"(WEINREICH, LABOV e HERZOG, 1968, p. 102. Tradução nossa).

Nesse sentido, é preciso compreender o que aconteceu historicamente em uma determinada língua em um determinado momento para que houvesse uma reconfiguração paramétrica ${ }^{33}$. Colocando a questão a partir de um exemplo concreto: todas as línguas germânicas antigas exibiam algum tipo de propriedade V2, ou seja, manifestavam o movimento do verbo para a posição mais alta na estrutura (AXEL, 2007; HINTERHÖLZL e PETROVA, 2010). Na atualidade, apenas o inglês, da família germânica, não possui mais a propriedade V2, tendo-a perdido por volta do século XV. Ora, se toda a família germânica possuía a mesma propriedade, por que razão apenas o inglês a perdeu? A resposta estrutural se restringe ao fato de ter havido uma reestruturação paramétrica, como Lightfoot (1991) demonstra. No entanto, o motivo de ter havido uma reestruturação paramétrica levando o inglês a perder a propriedade V2 é um problema sociohistórico ${ }^{34}$ porque, se não o fosse, o mesmo deveria ter acontecido com outras línguas germânicas, de maneira aleatória. $\mathrm{Ou}$, em última instância, o inglês poderia não ter perdido a propriedade V2 naquele momento mas em outro, ou poderia nem sequer tê-la perdido.

Voltando às considerações de Paixão de Sousa (2004), o interesse da gramática gerativa nos estudos históricos não reside apenas no fato de indicar que uma gramática B substituiu uma gramática A. Pelo contrário, vai mais além. Seu interesse reside no fato de explicar como uma gramática B substituiu uma gramática A. Dentro do quadro de mudança associado a questões de aquisição de linguagem, a conclusão tácita a que se chega é que, para o quadro gerativista, a mudança é abrupta.

O fato de a mudança ser abrupta não significa somente que, no âmbito do indivíduo, a mudança ocorre num dado ponto do tempo. Além disso, uma mudança pode desencadear outras, num tipo de efeito cascata. Kroch (1989) mostra, para a mudança do francês antigo para o francês da renascença que, quando o verbo para de se mover para a posição mais alta na estrutura, uma série de outras propriedades também são perdidas (por exemplo, a inversão V-S) e a contraparte derivada de uma gramática não V2 (por exemplo, a ordem S-V) é incrementada. Entretanto, dado que tem-se que considerar o espalhamento da mudança pela 
sociedade, no âmbito macro pode-se observar uma gradualidade na mudança linguistica. Os fatores sociohistóricos entram justamente em jogo nessa questão, conforme discutido em Kroch (2001) ${ }^{35}$. É nesse sentido que pode ser entendida a mudança internamente motivada: além das mudanças imediatamente esperadas, em função da mudança num parâmetro, outros efeitos posteriores seriam esperados, como se discute em Biberauer e Roberts (2008). No entanto, em última análise, o gatilho inicial de toda mudança seria de ordem externa.

0 quadro da sociolinguistica histórica, que ganhou força a partir dos anos 1980, a partir dos trabalhos de Romaine (1982) e Siegel (1985), permitiu que os problemas da transmissão e do encaixamento fossem abordados de maneira adequada, sendo pensados a partir das dinâmicas sociais e práticas linguísticas. 0 quadro gerativista sendo um quadro inicialmente cognitivista/mentalista, precisa beber dessas fontes sociohistóricas, como bem apontado por Chomsky (1997), para poder explicar a dinâmica da mudança gramatical, que significa a substituição de gramáticas, que é depreendida a partir dos textos (objetos históricos) que chegaram até os dias de hoje ${ }^{36}$.

\section{CONSIDERAÇÕES FINAIS}

A gramática gerativa surge na segunda metade dos anos 1950 no bojo da chamada Segunda Revolução Cognitiva, que afetou as ciências humanas no geral, deslocando o objeto de estudo dos produtos para os processos mentais geradores desses produtos. Inicialmente, como uma teoria cognitivista/mentalista, preocupada com a configuração da mente humana para a linguagem, com o argumento biológico de que a faculdade da linguagem é algo inerente à espécie humana dado geneticamente, a gramática gerativa não tinha nenhuma preocupação histórica nem social ${ }^{37}$.

No entanto, como a pesquisa avança, novas questões vão sendo colocadas e o gerativismo precisou se deparar com a questão crucial da mudança linguística como consequência dos estudos de sincronias passadas. Apontamos que o gerativismo, como uma teoria da mente, entende a mudança linguística como substituição de gramáticas através das gerações devido a uma alteração no ambiente linguístico que impossibilita que a gramática alcançada pela criança da geração posterior seja idêntica à gramática alcançada pela geração anterior, que é aquela que oferece os dados linguísticos primários para a criança. Esse fato coloca, diferentemente do que propôs Faraco (2005), o gerativismo em um lugar muito diferente do estruturalismo e do historicismo do século XIX porque, seguindo o Princípio da Inércia (ROBERTS, 2007), a mudança gramatical só acontece quando é provocada. Além disso, não há leis da direcionalidade da mudança. A mudança gramatical acontecerá de uma forma ou de outra a depender do que a criança encontre no seu ambiente linguístico de aquisição particular.

A hipótese de que a mudança gramatical acontece na aquisição da linguagem e só é desencadeada se for provocada insere os estudos de mudança sintática que seguem a perspectiva da gramática gerativa na chamada Linguística Histórica 
porque faz com que o pesquisador se confronte com os problemas da transmissão e da implementação das mudanças linguísticas. Em outras palavras, o pesquisador deve explicar por que uma reconfiguração paramétrica aconteceu naquele momento naquela gramática mas não aconteceu em outra gramática idêntica em outro lugar, ou mesmo na mesma gramática em outro momento. Essa questão não pode ser resolvida sem uma perspectiva sociohistórica.

Diversos trabalhos no quadro da gramática gerativa têm lidado com uma perspectiva sociohistórica, especialmente para tratar de como os contatos linguísticos alteram o ambiente linguístico e provocam mudanças gramaticais. Avelar e Galves (2014) fazem uma boa discussão de como as línguas africanas vindas com os negros escravizados para o Brasil podem ter participado na emergência da gramática do que se chama de português brasileiro. King (2000) mostra como o contato entre línguas (francês e inglês) influenciou o francês de Prince Edward Island no sentido de levar ao francês da região propriedades que não existem no francês da França ou mesmo de outras regiões do Canadá, mas são usadas em todas as variedades do inglês. Martins (2003) e Paixão de Sousa (2004) discutem como a relação sociohistórica entre Portugal e Espanha no final da Idade Média pode ter condicionado a gramática portuguesa, considerando que o castelhano era a língua de prestígio na Península Ibérica. E assim, muitos outros trabalhos têm sido feitos relacionando sociohistória com mudança gramatical no quadro gerativista.

A gramática gerativa se propõe um objetivo científico. Então, como modelo teórico, precisa propor explicações para o funcionamento do mundo, no caso, a faculdade da linguagem humana. À medida que o trabalho avança e algumas descobertas são feitas, é possível trazer novas questões para o modelo e procurar novas respostas. Isso foi o que sucedeu. Em 1960, a preocupação estava na caracterização da faculdade da linguagem como uma propriedade cognitiva implícita específica da espécie humana; em 1980, com a Teoria de Princípios e Parâmetros, o trabalho se desenvolveu tanto na comparação de línguas da atualidade como de fases antigas em busca das propriedades universais e particulares da faculdade da linguagem. Muitos outros desenvolvimentos foram alcançados a partir daí, entre os quais podemos citar a relação com a estrutura da informação e com a pragmática e a relação com aspectos sociais e históricos.

Insistir em que a gramática gerativa, quando olha para a história (cronologia) das línguas, é um modelo a-histórico, mesmo quando uma série de trabalhos dentro desse quadro teórico mostram com bastante clareza que o que acontece no ambiente linguístico é o aspecto fundamental nas explicações das mudanças gramaticais, reflete uma má compreensão profunda do que seja o estudo da mudança gramatical no quadro da gramática gerativa. Isso demonstra uma falta de atualização de tais estudos, de se guiarem pelo simples fato de essa teoria ter se originado num quadro teórico mentalista, inicialmente associal e a-histórico. 


\section{Notas}

* Pós-doutorando em Linguística na Universidade Estadual de Campinas (UNICAMP), com bolsa CAPES.

${ }^{1}$ Com base nas citações dos autores, Mattos e Silva (1988) define a linguística teórica como a perspectiva de estudo que busca o desvendamento do funcionamento do sistema ou da gramática e a linguística histórica como a perspectiva de estudo que engloba tudo o que não está incluído na linguística teórica, ou seja, todo o estudo que não esteja preocupado em explicar e explicitar a faculdade da linguagem dos homens.

2 Concordamos com as definições propostas por Mattos e Silva $(1988,1999)$ em vários sentidos. A Linguística Histórica, como o estudo do linguístico relacionado aos aspectos sociopolítico e histórico, não pode estar restrita ao estudo da mudança linguística propriamente dita. Linguística histórica e linguística diacrônica devem distinguir-se em alguma medida. Contudo, acreditamos que a linguística diacrônica seja um primeiro passo para a linguística histórica stricto sensu. 0 estudo da língua numa perspectiva puramente diacrônica oferece resultados parciais e, algumas vezes, equivocados, da mudança linguística.

${ }^{3}$ Precisamos enfatizar que é do ponto de vista gramatical porque é obvio e evidente que as línguas se distinguem do ponto de vista lexical, fazendo com que cada significado possa ter um significante diferente em cada língua: house, casa, maison etc. para designar o lugar onde se mora. Também é evidente que as línguas são diferentes do ponto de vista fonológico. Por fim, precisamos enfatizar que é do ponto de vista gramatical porque o objetivo inicial e maior do gerativista é a compreensão do nível gramatical, mais especificamente, da sintaxe.

${ }^{4}$ Chomsky (1986a) discute os diversos conceitos de língua, tanto na perspectiva do senso comum como na perspectiva da teoria linguística e propõe que, cientificamente, haja duas definições de língua: língua-E e língua-I. Retornaremos a essa questão mais abaixo.

${ }^{5} \mathrm{E}$ aqui o leitor deve ter em mente que não se trata de estudos comparativos de sincronias diferentes. Esse estudo pode continuar associal e a-histórico. 0 ponto a que estamos nos referindo precisamente é quando o gerativismo passa se preocupar com as dinâmicas da mudança linguística.

60 termo "meramente" deve ser tomado com muita cautela. Fazer descrições cuidadosas e precisas de etapas antigas de uma língua, muitas vezes já ininteligível, não é um trabalho simples nem simplório. Apenas é inicial e insuficiente.

7 Também poderia ser evocado aqui o Princípio da Uniformidade, de Labov (1972, p. 161): "os mesmos mecanismos que operaram para produzir as mudanças de grande escala do passado podem ser observados operando nas mudanças atuais ocorrendo em torno de nós" (tradução nossa).

8 É preciso notar que ainda hoje se fazem críticas ao gerativismo com base em argumentos que os próprios gerativistas reformularam ou abandonaram. Por exemplo, é comum ainda hoje a crítica ao falante-ouvinte ideal de Chomsky (1965) mesmo quando Chomsky (1986a) reconhece e assume que as comunidades de fala podem ser heterogêneas. Muitos trabalhos gerativistas recentes incluem a variação social nas suas explicações bem como, como no caso dos estudos da chamada periferia esquerda da oração, a relação com a pragmática e a estrutura da informação. Ou seja, os estudos gerativistas avançaram muito para além das propostas iniciais de Chomsky (1965), que não estavam equivocadas, mas 
apenas tinham objetivos mais restritos, em parte pelo estágio do trabalho investigativo em que a teoria se encontrava.

${ }^{9}$ Chomsky (1986a, p. 18) afirma que "fazendo essas idealizações explícitas e perseguindo nossa pesquisa de acordo com elas, nós não prejudicamos de nenhum modo o estudo da língua como um produto social". E continua: "Note também que o estudo da lingua(gem) e da GU conduzido dentro do modelo da psicologia individual permite a possibilidade de que o estado de conhecimento obtido pode ele mesmo incluir algum tipo de referência à natureza social da lingua(gem)" (traduções nossas).

10 Essa discussão volta a ser explorada em Chomsky (1986a).

11 Chomsky (1975) faz um paralelo com outros órgãos do ser humano: o ser humano enxerga o mundo da forma como enxerga (e, neste ponto, enxergar se refere unicamente ao aspecto físico-biológico da visão, captação da imagem a partir dos olhos) porque o seu cérebro está preparado para enxergar dessa forma e não de outra.

12 Por exemplo, Guimarães e Orlandi (2006, p. 149-150) dizem que "O objeto da linguística é para esta posição o que Chomsky chama de competência linguística. [...] Esta competência é considerada inata, na medida mesmo em que é biológica". Como se pode ver, essa afirmação não é correta. A competência linguística não é inata. É, necessariamente, adquirida a partir da interação com o ambiente linguístico.

13 Os argumentos para o inatismo são vários: a) só seres humanos adquirem uma língua; b) a aquisição da linguagem é algo compulsório e involuntário; c) as etapas de aquisição são relativamente uniformes ao redor do mundo; d) a aquisição da linguagem não depende de outras habilidades cognitivas; e) ninguém efetivamente ensina a criança a falar e o input é degenerado e imperfeito. Se não houvesse algum mecanismo mental, dado de graça pela genética, a tarefa de adquirir uma língua seria impossível.

14 Chomsky (1986a) destaca, uma vez mais, que a noção de oração foi deixada, pelo estruturalismo saussureano, numa espécie de limbo, talvez para ser incluída no estudo do uso.

15 O leitor interessado pode consultar a ampla discussão sobre sintaxe diacrônica feita em Roberts (2007).

16 Esse aspecto merece o comentário de que a mudança é uma possibilidade mas não uma obrigação. As línguas não mudam necessariamente. Uma boa discussão sobre a questão é feita em Paixão de Souza (2006) quando retoma a questão de se as mudanças são endógenas (internamente motivadas) ou exógenas (externamente motivadas). Tuten (2003) toca na questão quando se pergunta por que línguas do mesmo tipo e com as mesmas características não mudam ao mesmo tempo ou mudam em direções diferentes, por exemplo. A conclusão a que se chega é que alguma coisa externa à própria língua deve ocasionar a mudança.

17 Tomaremos como marco a discussão a partir do modelo de Princípios e Parâmetros porque é infrutífero discutir teorias já obsoletas que nem mesmo os gerativistas utilizam. 0 modelo de Princípios e Parâmetros traz uma ruptura com os modelos anteriores, baseados em regras, e considera que somente aspectos conceituais dos modelos anteriores da teoria gerativista devam ser aproveitados como, por exemplo, as noções de competência e desempenho, a postulação de uma faculdade da linguagem etc. Discutir como essa faculdade da linguagem se constitui, por exemplo, só tem sentido atualmente se for abordado a partir da teoria de Princípios e Parâmetros, que é o modelo vigente, apesar das inúmeras reformulações e desmembramentos suscitados a partir do Programa Minimalista (CHOMSKY, 1993). 
18 Lightfoot (1991) é um bom exemplo do que mencionamos acima da fala de Mattos e Silva (1988): a linguística teórica se alimentando da linguística histórica para formulações de seus modelos.

19 Lightfoot (1991) destaca que o francês apresenta alternância entre "que/quem" no complementizador (conjunção e pronomes relativos) se o complementizador rege um sujeito nulo ou não, como mostram os dados de Lightfoot (1991, p. 31):

(i) Qui crois-tu qui/*que est parti?

"Quem você acha que saiu?"

(ii) Qui crois-tu que/*qui Marie a vu?

"Quem você acha que a Maria viu?"

Nesse sentido, Lighfoot (1991, p. 31-32) destaca que a noção de material subordinado (embedded material) não deve ser tomada no sentido de orações mas de domínios de vinculação porque um dado constituinte pode estar numa oração subordinada mas ser pertencente ao domínio matriz já que oração e domínio não se equivalem.

20 Trata-se da noção de subjacência, tomada de Chomsky (1986b), segundo a qual os movimentos devem ser cíclicos, isto é, os constituintes devem fazer paradas na borda de cada oração, quando se movem de um domínio subordinado para um domínio matriz.

${ }^{21}$ Aqui merecem ser feitas duas observações: a) a família de línguas V2 é bastante variada com relação aos efeitos secundários do fenômeno; b) Uma pequena ressalva é que o fato de uma língua ter a ordem linear em que o verbo está em segunda posição, como "João disse que Maria vem hoje", não faz de uma língua uma língua V2. Língua V2 se refere a propriedades estruturais e não apenas lineares.

22 Diversos trabalhos pontuaram que as línguas românicas antigas também tenham sido línguas V2: Ribeiro (1995) para o português, Fontana (1993) para o espanhol, Adams (1987) para o francês entre outros.

${ }^{23}$ Por razões de espaço, não poderemos discorrer sobre noções teóricas como regência e o princípio das categorias vazias. Remetemos o leitor interessado à discussão de Chomsky (1986b).

24 A proposta de Lightfoot (1991) é refinada e ampliada em Lightfoot $(1998,2006)$. Lightfoot (1998) lança o modelo de cues ('pistas'), no qual a criança fixaria parâmetros a partir das pistas que encontra no input. Um exemplo de pistas para aquisição pode ser obtido a partir das línguas V2. Lightfoot $(1991,1995,2006)$ propõe que a pista que uma criança tem para saber que sua língua é uma língua $V 2$ é a existência de um constituinte qualquer, independentemente de qualquer função gramatical ou papel temático, em primeira posição seguido imediatamente pelo verbo. Considerando que o espírito da discussão é o mesmo (a aquisição da linguagem como o ponto central da mudança linguística) e que o debate sempre gira em torno da fixação de parâmetros pela criança, nos limitaremos à apresentação da proposta inicial.

Uma última observação, entretanto, é que os trabalhos em aquisição da linguagem têm discutido esse aspecto da fixação de parâmetros. Algumas questões intrigantes são colocadas: a) o que acontece se a criança não encontra a pista até determinado momento? Roberts e Roussou (2003) propõem um mecanismo de segurança que determina que, se uma determinada pista não é encontrada, a criança fixa a opção mais econômica do parâmetro; b) até que momento a criança espera a pista?; c) que quantidade de dados é 
necessária para ser caracterizada como uma pista? Os trabalhos de Lightfoot $(1998,2006)$, por exemplo, tentam dar alguma resposta a essas questões.

${ }^{25}$ Roberts e Roussou (2003) dizem, nesse sentido, que a aquisição da linguagem é um processo fracamente determinístico, no sentido de que a fixação de parâmetros deve ser convergente com o input e não com a gramática da geração anterior. Fixação correta de parâmetros, assim, significa obter uma gramática compatível com o input recebido. Esse ponto, como voltaremos a discutir mais adiante, é crucial para que os estudos diacrônicos no quadro da gramática gerativa se insiram no âmbito da linguística histórica.

${ }^{26}$ Essa discussão requereria um pouco de conhecimento da Teoria-X e outros aspectos da Teoria de Princípios e Parâmetros. Tentaremos simplificar ao máximo a explicação para o leitor não familiarizado. De maneira resumida, verbo e objeto precisam estar juntos no ponto inicial da derivação, por exemplo, por razões semânticas. Se aparecem separadamente, um dos dois elementos foi movido para alguma posição diferente da originária. Um exemplo de movimento muito conhecido dos falantes de português brasileiro é o chamado movimento-QU:

(i) João disse que seu pai comprou o livro.

(ii) João disse que seu pai comprou o quê?

(iii) 0 que João disse que seu pai comprou?

"o livro" em (i) é o complemento do verbo comprar. "o quê" em (ii) é a contraparte interrogativa do complemento do verbo e está numa posição adjacente. "o que" em (iii) é o resultado do movimento do interrogativo da posição adjacente ao verbo para uma posição mais alta (à esquerda) da oração. Sabe-se que o elemento foi movido porque, apesar de estar longe do núcleo verbal, é interpretado semanticamente como complemento dele.

${ }^{27}$ Lightfoot (1991, p. 55) indica que esse dado é encontrado nas falas de mães dirigindo-se às crianças, refletindo um tipo de fala infantil em que as categorias funcionais são ausentes.

28 Tuten (2003, p. 29) toma o conceito de acomodação de Giles (1973, p. 90): "se um remetente em uma situação diádica desejar obter a aprovação do receptor, então ele pode adaptar seus padrões de sotaque àquele dessa pessoa, isto é, reduzir as diferenças de pronúncia" (tradução nossa), acrescentando, em seguida, que a acomodação pode afetar qualquer nível de análise linguistico.

29 É preciso observar como as análises de Lightfoot (1991) e Kroch (2001) podem ser compatibilizadas para explicar a perda do efeito V2 na história do inglês.

30 Paixão de Sousa (2004) discute esse aspecto indicando que mudança gramatical e mudança linguística não são sinônimos. A mudança linguística é o que se registra nos textos (produtos). A mudança gramatical tem a ver com as representações mentais. Uma mudança linguística não necessariamente tem por detrás uma mudança gramatical.

31 Esse ponto traz alternativas interessantes: por um lado, pode-se considerar que a ausência implique em agramaticalidade (o que pode ser bastante problemático já que, como indicado, o texto representa apenas um fragmento da língua); por outro lado, como gramáticas são estruturas atemporais determinadas pela faculdade da linguagem, pode ser feito um trabalho comparativo com línguas da atualidade (como feito por LIGHTFOOT, 1991). De todos os modos, a impossibilidade de operar com evidências negativas se torna extremamente interessante na medida em que a aquisição da linguagem é o lugar da 
mudança porque durante a aquisição a criança só tem evidências positivas para adquirir sua língua. A criança fixa os parâmetros somente a partir do que ouve. Nesse sentido, a ausência de evidências negativas leva o pesquisador a se esforçar para entender como a criança fixou parâmetros de forma diferente a partir dos dados positivos que teve a sua disposição.

32 Ora, se a criança pudesse mudar a língua sem mudança no ambiente linguístico, os dados de nada serviriam e as mudanças seriam aleatórias e cada criança poderia fixar parâmetros de formas diferentes. A questão coloca, mais uma vez, o ambiente linguístico no qual a criança adquire a língua como fator determinante para a aquisição da linguagem.

33 Roberts (2007, p. 232) assume o Princípio da Inércia, que diz que a mudança sintática não acontece a menos que seja causada.

34 Kroch (2001) apresenta uma breve explicação para a questão com base no modelo de competição de gramáticas e contato linguístico.

35 Por questão de espaço e propósito, não poderemos aprofundar a discussão sobre a mudança linguística ser gradual ou abrupta. Recomendamos a leitura de Kroch (2001) para maiores esclarecimentos.

36 Desde os anos 1980, se trabalha no Brasil conjugando a perspectiva variacionista com a perspectiva gerativista, conforme vários trabalhos de Fernando Tarallo e Mary Kato indicaram. Tarallo (1991) já havia indicado que não incompatibilidade real entre as duas perspectivas porque cada uma delas ataca um problema da mudança linguistica diferente. Para uma boa discussão de como os dois modelos podem ser compatibilizados e produzir resultados profícuos, ver Lucchesi e Ribeiro (2009).

37 Como já indicado, Chomsky (1975) entende a faculdade da linguagem como um órgão do ser humano como outro qualquer. Nesse sentido, não é plausível imaginar que o coração humano tenha sofrido alguma alteração do ano de 1500 para o ano de 2010 ou que o coração do brasileiro seja diferente do coração do japonês.

\section{Referências}

ADAMS, Marianne. Old French, Null Subjects and Verb Second Phenomena. 1987. Ph.D. Dissertation, University of California.

AVELAR, Juanito; GALVES, Charlotte. O papel das línguas africanas na emergência da gramática do português brasileiro. Lingüística, v. 30, n.2, p.241-288, 2014.

AXEL, Katrin. Studies on Old High German Syntax Left sentence periphery, verb placement and verb-second. Amsterdam / Philadelphia: John Benjamins Publishing Company, 2007.

BATTYE, Adrian; ROBERTS, Ian. Clause structure and language change. Nova Iorque/ Oxford: Oxford University Press, 1995.

BIBERAUER, Theresa; ROBERTS, Ian. Cascading parameter changes: Internally-driven change in Middle and Early Modern English. In: EYTHÓRSSON, Thórhalur (org.) Grammatical Change and Linguistic Theory: The Rosendal Papers. Amsterdam: John Benjamins, 2008. p. 79-113.

CHOMSKY, Noam. Novos horizontes nos estudos da linguagem. D.E.L.T.A., v. 13, número especial, p. 49-72, 1997. 
A minimalism program for linguistic theory. In: HALE, K.; KEYSER, S. J. (orgs.). The

view from Building 20. Cambridge/Mass.: The MIT Press, 1993. p. 1-52.

Knowledge of Language: Its nature, origin and use. New York: Praeger, 1986a.

Barriers. Cambridge, Mass.: The MIT Press, 1986b.

Lectures on Government and Binding. Dordrecht: Foris, 1981.

Reflections on language. Nova Iorque: Pantheon, 1975.

Aspects of the theory of syntax. Cambridge/Massachusets: The MIT Press, 1965.

Syntactic Structures. Nova Iorque/Berlin: Mouton de Gruyter, 1957.

COSERIU, Eugenio. Sincronia, Diacronia e História: o problema da mudança lingüística. Tradução de Carlos A. da Fonseca e Mário Ferreiro. Rio de Janeiro: Presença, 1979.

DEN BESTEN, Hans. On the Interaction of Root Transformations and Lexical Deletive Rules. Studies in West Germanic Syntax, n. 20, p. 14 -100, 1989.

FARACO, Carlos Alberto. Linguistica histórica. Uma introdução ao estudo da história das línguas. São Paulo: Parábola, 2005.

FONTANA, Josep María. Phrase structure and the Syntax of clitics in the history of Spanish. 1993. Ph.D Dissertation, University of Pennsilvanya.

GALVES, Charlotte. Ensaios sobre a gramática do português. Campinas: Editora da Unicamp, 2001.

GAUGER, Hans-Martin. Introducción a la lingüística románica. Madri: Gredos, 1989.

GILES, Howard. Accent mobility: A model and some data. Anthropological Linguistics, v. 15, p. 87-105, 1973.

GUIMARÃES, Eduardo; ORLANDI, Eni. O conhecimento sobre a linguagem. In: PFEIFFER, Claudia; NUNES, José Horta (orgs.). Linguagem, história e conhecimento. Campinas: Pontes, 2006. p. 141-157.

HAIDER, Hubert; PRINZHORN, Martin. Verb second Phenomena in Germanic languages. Dordrecht: Foris, 1986.

HINTERHÖLZL, Roland; PETROVA, Svetlana. From V1 to V2 in West Germanic. Lingua, v. 120 , issue 2, p. 315-328, 2010.

KING, Ruth. The Lexical Basis of Grammatical Borrowing: A Prince Edward Island Case Study. Amsterdam: John Benjamins, 2000.

KROCH, Anthony. Syntactic Change. In: BALTIN, Mark; COLLINS, Chris (orgs.). The Handbook of Contemporary Syntactic Theory. Oxford: Blackwell, 2001. p. 699-730.

Reflexes of Grammar in Patterns of Language Change. Language Variation and Change, v. 1, p. 199-244, 1989.

LABOV, William. Sociolinguistic Patterns. Philadelphia, University of Pennsylvania Press, 1972.

LIGHTFOOT, David. How new languages emerge. Cambridge: Cambridge University Press, 2006.

Cue-based acquisition and change in grammars. In: The development of language, acquisition, change and evolution. Oxford: Blackwell, 1998. p. 144-177. 
Why UG needs a learning theory: Triggering verb movement. In: BATTYE, Adrian; ROBERTS, Ian (orgs). Clause structure and language change. Nova Iorque/Oxford: Oxford University Press, 1995. p. 31-52.

How to set parameters: Arguments from Language Change. Cambridge, Massachucetts: The MIT Press, 1991.

LUCCHESI, Dante; RIBEIRO, Ilza. Teorias da estrutura e da mudança linguísticas e o contato entre línguas. In: LUCHESI, Dante, BAXTER, Alan e RIBEIRO, Ilza. o português afro-brasileiro. Salvador, EDUFBA, 2009. p. 125-153.

MARTINS, Ana Maria. From unity to diversity in Romance syntax: A diachronic perspective of clitic placement in Portuguese and Spanish. In: BRAUNMÜLLER, Kurt; FERRARESI, Gisella (orgs.). Aspects of Multilingualism in European Language History. Amsterdam / Philadelphia: John Benjamins, 2003. p. 201-233.

MATTOS E SILVA, Rosa Virgínia. Orientações atuais da linguistica histórica brasileira. D.E.L.T.A., v. 5, número especial, p. 147-166, 1999.

Fluxo e Refluxo: uma retrospectiva da lingüística histórica no Brasil. D.E.L.T.A., v. 4, número 1, p. 85-113, 1988.

NEVALAINEN,Terttu; RAMOLIN-BRUNBERG, Helena. Historical Sociolinguistics: Origins, Motivations, and Paradigms. In: HERNÁNDEZ-CAMPOY, J. M.; CONDE-SILVESTRE, J. C. (orgs.) The Handbook of Historical Sociolinguistics. Malden/Oxford/ Chichester: Willey- Blackwell, 2012. p. 22-40.

PAIXÃO DE SOUSA, Maria Clara. Lingüística histórica. In: PFEIFFER, Claudia; NUNES, José Horta (orgs.). Linguagem, história e conhecimento. Campinas: Pontes, 2006. p. 11-48.

Língua Barroca: sintaxe e história no português nos anos 1600. 2004. Tese (Doutorado em Linguística). Universidade Estadual de Campinas.

RIBEIRO, Ilza. A sintaxe da ordem no português arcaico. O efeito V2. 1995. Tese (Doutorado em Linguística). Universidade Estadual de Campinas.

ROBERTS, Ian. Diachronic Syntax. Nova Iorque: Oxford University Press, 2007.

ROBERTS, Ian; KATO, Mary. Português brasileiro. uma viagem diacrônica. Campinas. Editora da Unicamp, 1993.

ROBERTS, Ian; ROUSSOU, Anna. Syntactic change: a minimalist approach to grammaticalization. Cambridge: Cambridge University Press, 2003.

ROMAINE, Suzanne. Socio-Historical Linguistics. Its Status and Methodology. Cambridge University Press, 1982.

SIEGEL, Jeff. Koines and koineization. Languages in Society, v. 14, p. 357-378, 1985.

TARALLO, Fernando. Reflexões sobre o conceito de mudança linguistica. Organon, v. 18, p. 11-22, 1991.

TUTEN, Donald. Koineization in Medieval Spanish. Berlin/Nova Iorque, Mouton de Gruyter, 2003.

VIKNER, Sten. Verb movement and expletive subjects in the Germanic languages. Oxford: Oxford University Press, 1995.

WEINREICH, U; LABOV, W.; HERZOG, M. I.. Empirical Foundations for a Theory of Language Change. In: LEHMANN, W. P. (org.). Directions for Historical Linguistics: A Symposium. Austin: University of Texas Press, 1968. p. 95-195. 
Para citar este artigo

PINTO, C. F. da C., ANDRADE, A. L. de. Desmistificando a gramática gerativa como uma teoria associal e a-histórica da mudança linguística. Macabéa - Revista Eletrônica do Netlli, Crato, v. 8., n. 2., 2019, p. 36-66.

\section{Os Autores}

Carlos Felipe da Conceição Pinto: É Graduado em Letras (Língua Espanhola) pela Universidade Federal da Bahia e Doutor em Linguística pela Universidade Estadual de Campinas. Tem experiência na área de Descrição e Análise Linguística, com ênfase em Sintaxe e Linguística Histórica. Atualmente é Professor Adjunto da Universidade Federal da Bahia, onde atua nas áreas de língua espanhola e linguística. Também é Docente Permanente (orientador de mestrado e doutorado) no Programa de Pós-Graduação em Língua e Cultura (PPGLinC-UFBA) e é Líder do "Grupo de Estudos Linguísticos Hispânicos" (UFBA/CNPq). De 01/04/2019 a 31/03/2020, encontra-se afastado para realização de Estágio Pós-Doutoral, com bolsa do Programa Nacional de Pós-Doutorado (CAPES), sob a supervisão da Prof ${ }^{\mathfrak{a}}$. Drậ. Charlotte Galves, na Universidade Estadual de Campinas.

Aroldo Leal de Andrade: É professor adjunto junto à Faculdade de Letras da Universidade Federal de Minas Gerais (FALE/UFMG). Em 2016 e 2017 trabalhou junto à Universidade da Integração Internacional da Lusofonia Afro-Brasileira (Unilab). Realizou pós-doutorado na Universidade Estadual de Campinas (Unicamp) e na Universidade do Quebec em Montreal. É doutor em linguística pela Unicamp, mestre em linguística e bacharel em relações internacionais pela Universidade de Brasília. 